\title{
Collaboration of high activity soil and geological structure factors in Pagelaran soil creep occurrence, Indonesia
}

\author{
Salam Ahmad F. ${ }^{1}$, Kristyanto T. H. W. ${ }^{2,}{ }^{*}$, and Asriza ${ }^{3}$, Syahputra Reza ${ }^{2}$, Tempessy Albert S. ${ }^{2}$, Indra Tito L. $^{2}$ \\ ${ }^{1}$ Resevoir Geophysics Graduate Program FMIPA Universitas Indonesia, 16424 Depok, Indonesia \\ ${ }^{2}$ Geology Study Program FMIPA Universitas Indonesia, 16424 Depok, Indonesia \\ ${ }^{3}$ Geophysics Study Program FMIPA Universitas Indonesia, 16424 Depok, Indonesia
}

\begin{abstract}
Soil creep is a landslide that moves slowly but it does not mean harmless. Soil creep that succeeded in forcing the citizens to migrate occurred in Pagelaran by wiping out 13 houses. This paper aims to know the contribution of geological structures and physical properties of soil toward the creeping occurrence. The methods used in this research consist of geological structure mapping; soil sampling; laboratory works; and analysis of geological structures and soil activity. Geological structures analysis indicates that the main force worked predominantly in NE-SW direction, parallel with creeping. It expresses that the creep was influenced by the orientation of them. Additionally, their distribution can be used as access for rainwater to infiltrate and add to the burden of the slopes. While laboratory results show that, the soil is classified into $\mathrm{MH}$ and $\mathrm{CH}$. Calculation of activity numbers of soil indicates that it has a high - very high activity with value between $0.705-1.4931$ (Skempton, 1953). It means that the soil will swell easily if contaminated by water.
\end{abstract}

\section{Introduction}

Soil creep is one type of landslide that has unique characteristic. It is the slow movement of soil materials down slopes under the influence of gravity. This type of land movement moving slowly, but it does not mean harmless $[1,2]$. One of soil creep that succeeded in forcing the population to migrate en masse occurred in one of the villages in Pagelaran, Cianjur, West Java. This landslide wiped out 13 houses and collapsed road along 280 meters [3].

Soil creeps usually occurs during and after rain. The amount of creep has a positive correlation with the amount of rain and increase in soil moisture. Soil creeps, mostly, are triggered by soil contained with active clay minerals, such as kaolinite or montmorillonite. This kind of mineral cause the soil has high activity number [4]. It means that the slope, which is formed by high activity soil, can be prone to creep [5]. On the other hand, landslide, including soil creep, also can be influenced by geological structures [6,7]. Their orientation can affect the slope stability if it has the same or inline orientation with the orientation of the slope [8].

Geological structures, as discontinuities, also can be access for water to flow inside the slope and affect the properties of soil [9]. Therefore, this paper aims to know the contribution of physical properties of soil, which is represented by its activities, and geological structures that develop at the site of research on the occurrence of the soil creep.

\section{Geological setting}

\subsection{Geomorphology}

Geographically, Pagelaran, Cianjur located in $7^{\circ} 08^{\prime} 48.9^{\prime \prime} \mathrm{S} 107^{\circ} 12^{\prime} 05.3^{\prime \prime} \mathrm{E}$ which is part of Southern West Java Mountain. This zone, triangular facet highland, is culminating in Bandung and extending from West to East. Overall, geomorphology of the zone is slightly sloping geanticline. The geomorphology of this area was affected by rejuvenation process (peneplain), lifting and re-sedimentation of erosion material. Thus in some area, the surface is not plateau, but narrow and deep valleys shaped. Van Bemmelen [10] concluded that not all of the Southern West Java Mountains were drown by sea level when late Miocene transgressions occur. Geological processes during the formation process, differences in the hardness and type of rock, and geological structure that occur in this area [11] influence morphology of this area.

\subsection{Stratigraphy}

Bedrock that formed sliding surface of this area, based on Sindangbarang Geological map and its Stratigraphic column [12], is Bentang Formation (Late Miocene). This formation containing less compressible tuff sandstone, crystal tuff and pumice tuff with globigerina clay, silt stone, breccia (andesite) and conglomerate. Then Koloberes Formation was deposited above the Bentang Formation. Koloberes Formation tends to be

Corresponding author: twin.hosea@hotmail.com 
similar with the Bentang Formation, which consists of well-layered sandstone, tuff breccia, and brownish grey sandstone.

\subsection{Tectonics}

Geological structures that developed in research area was faults, lineament, folds, and joints, which can be found in Oligocene - Miocene rocks and Quaternary one. Faults that spread out in research area are in the forms of NW-SE strike-slip faults and N-S normal faults. Folds that found there are SW-NE anticline and SW-NE syncline. Lineament that lies in study area is interpreted as fault with orientation NW-SE and SW-NE. Joints can be commonly found in Oligo-Miocene rocks [12].

\section{Methods}

\subsection{Field Works}

Field works that conducted in this research are geotechnical drilling and geological structure mapping. Geotechnical drilling was done to get subsurface information, i.e. soil lithology, and undisturbed soil samples for laboratory analysis. Figure 1a shows the activity of drilling in research area.

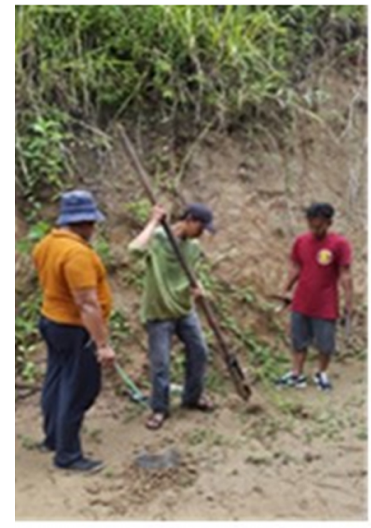

a

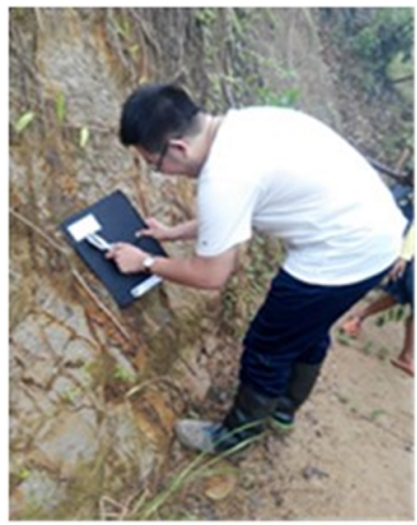

$\mathrm{b}$
Fig. 1. (a) Drilling activity and (b) joint orientation measurement

Geological structure mapping was done by investigating outcrop and measuring the orientation of geological structures. Measurement of it also conducted towards cracks on the surface of slope. Figure 1b shows the measurement activity of cracks and joints.

\subsection{Laboratory analysis}

\subsubsection{Grain size analysis}

The purpose of this analysis is to determine grain size distribution of the soil sample. This method using sieve test equipment to classify soil type based on USCS classification [13]. Table 1 and 2 show the results of grain size analysis and the classification of the soil based on USCS.

\subsubsection{Atterberg Limit Test}

Atterberg limits are a basic method to measuring PI (plasticity index), plastic limit (PL), and liquid limit (LL) of the fine-grained soil (silt and clay) with water content changes. If we know the value of this parameter, then generally soil properties can be known.

\subsection{Studio analysis}

Studio analyses are in the form of geological structure, and physical properties (Atterberg Limits, Plasticity Index, and Activity Number) analyses. Geological structures analysis is done to know the orientation of them and compare with the orientation of slope.

Physical properties analyses were using Casagrande method [14], Gillot Method [15] and the Method of Seed et al. [16], and method of William and Donaldson [17]. Casagrande method [14] was done to know the properties and classification of fine soil regarding with its plasticity.

Gillot method [15] and William and Donaldson method [17] was done to know the relationship between clay particle content and PI. While, Seed et al. [16] method was done to know the relationship betwen clay particle content and acitvity number of soil. Three of them were done to predict the activity number of soil that represents the swelling potential of soil.

\section{Results and discussion}

\subsection{Physical properties}

The results of laboratory test are shown in Tab. I and II in Appendix. These results are tested from undisturbed soil samples. Laboratory tests that were conducted consisted of Atterberg Limits and Plasticity Index.

\subsection{Casagrande method (1948)}

Based on the results of laboratory tests using Casagrande method ([14], there are two types of soil in research area, they are Clay High Plasticity $(\mathrm{CH})$ and Silt High Plasticity $(\mathrm{MH})$. Figure 2 show the graphic of the results of this test.

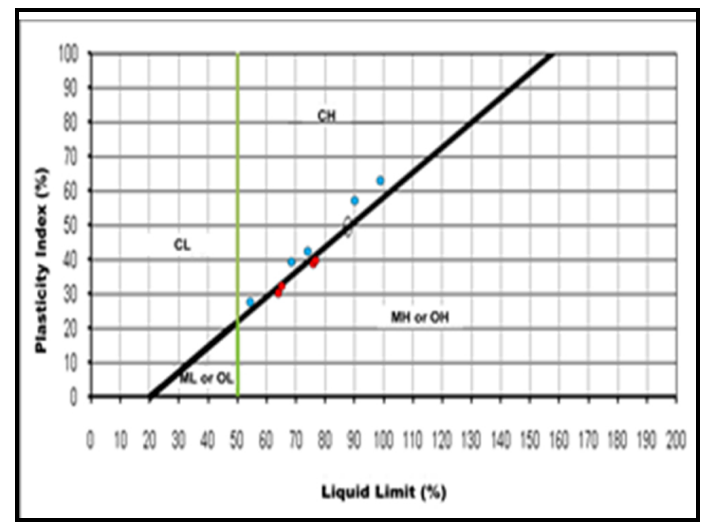

Fig. 2. Diagram of Casagrande method [14]. 
Table. 1. Physical properties of soil in toe of slope

\begin{tabular}{|c|c|c|c|c|c|c|c|c|c|}
\hline \multirow{3}{*}{$\begin{array}{c}\text { Sample } \\
\text { Depth (m) }\end{array}$} & \multirow{3}{*}{$\begin{array}{c}\text { Soil } \\
\text { Description }\end{array}$} & \multicolumn{8}{|c|}{ Laboratory Test Result } \\
\hline & & \multicolumn{3}{|c|}{ Atterberg Limit Test } & \multicolumn{4}{|c|}{ Grain Size Distribution } & \multirow[t]{2}{*}{ USCS } \\
\hline & & $\begin{array}{l}\text { LL } \\
(\%)\end{array}$ & $\begin{array}{l}\text { PL } \\
(\%)\end{array}$ & $\begin{array}{c}\text { PI } \\
(\%)\end{array}$ & $\begin{array}{c}\text { Gravel } \\
(\%)\end{array}$ & $\begin{array}{l}\text { Sand } \\
(\%)\end{array}$ & $\begin{array}{l}\text { Silt } \\
(\%)\end{array}$ & $\begin{array}{l}\text { Clay } \\
(\%)\end{array}$ & \\
\hline $0.00-0.50$ & $\begin{array}{c}\text { Silty Clay, } \\
\text { Brown, High } \\
\text { Plasticity }\end{array}$ & 90.24 & 34.50 & 55.69 & 0.00 & 18.00 & 32.40 & 49.60 & $\mathrm{CH}$ \\
\hline $\mathrm{N} / \mathrm{A}$ & $\mathrm{N} / \mathrm{A}$ & N/A & N/A & $\mathrm{N} / \mathrm{A}$ & $\mathrm{N} / \mathrm{A}$ & $\mathrm{N} / \mathrm{A}$ & N/A & $\mathrm{N} / \mathrm{A}$ & N/A \\
\hline $1.00-1.50$ & $\begin{array}{l}\text { grades with } \\
\text { sand }\end{array}$ & 54.81 & 57.60 & 27.23 & 0.00 & 21.80 & 34.60 & 43.60 & $\mathrm{CH}$ \\
\hline $1.50-2.00$ & Same as above & 68.79 & 29.60 & 39.16 & 0.00 & 21.80 & 32.90 & 45.30 & $\mathrm{CH}$ \\
\hline $2.00-2.50$ & Same as above & 74.48 & 32.10 & 42.41 & 0.00 & 6.00 & 43.00 & 51.00 & $\mathrm{CH}$ \\
\hline $2.50-3.00$ & Same as above & 99.31 & 36.00 & 63.31 & 0.00 & 16.40 & 36.20 & 47.40 & $\mathrm{CH}$ \\
\hline
\end{tabular}

Table. 2. Physical properties of soil in top of slope

\begin{tabular}{|c|c|c|c|c|c|c|c|c|c|}
\hline \multirow{3}{*}{$\begin{array}{c}\text { Sample } \\
\text { Depth (m) }\end{array}$} & \multirow{3}{*}{ Soil Description } & \multicolumn{8}{|c|}{ Laboratory Test Result } \\
\hline & & \multicolumn{3}{|c|}{ Atterberg Limit Test } & \multicolumn{4}{|c|}{ Grain Size Distribution } & \multirow[t]{2}{*}{ USCS } \\
\hline & & $\begin{array}{l}\text { LL } \\
(\%)\end{array}$ & $\begin{array}{l}\text { PL } \\
(\%)\end{array}$ & $\begin{array}{c}\text { PI } \\
(\%)\end{array}$ & $\begin{array}{c}\text { Gravel } \\
(\%)\end{array}$ & $\begin{array}{c}\text { Sand } \\
(\%)\end{array}$ & $\begin{array}{l}\text { Silt } \\
(\%)\end{array}$ & $\begin{array}{c}\text { Clay } \\
(\%)\end{array}$ & \\
\hline $0.00-0.50$ & $\begin{array}{l}\text { Silty Clay, Brown, } \\
\text { High Plasticity }\end{array}$ & 90.24 & 34.50 & 55.69 & 0.00 & 18.00 & 32.40 & 49.60 & $\mathrm{CH}$ \\
\hline N/A & $\mathrm{N} / \mathrm{A}$ & N/A & N/A & N/A & N/A & N/A & N/A & N/A & N/A \\
\hline $1.00-1.50$ & grades with sand & 54.81 & 57.60 & 27.23 & 0.00 & 21.80 & 34.60 & 43.60 & $\mathrm{CH}$ \\
\hline $1.50-2.00$ & Same as above & 68.79 & 29.60 & 39.16 & 0.00 & 21.80 & 32.90 & 45.30 & $\mathrm{CH}$ \\
\hline $2.00-2.50$ & Same as above & 74.48 & 32.10 & 42.41 & 0.00 & 6.00 & 43.00 & 51.00 & $\mathrm{CH}$ \\
\hline $2.50-3.00$ & Same as above & 99.31 & 36.00 & 63.31 & 0.00 & 16.40 & 36.20 & 47.40 & $\mathrm{CH}$ \\
\hline
\end{tabular}

Blue dots represent sample from the base of the slope and the red one represents the top part of the slope.

\subsection{Activity number analysis}

Based on the Atterberg Limits Analysis and grains size distribution analysis, soil that formed the slope has a number of activities ranging between high to very high. Figure 3 shows the plot diagram between $\%$ of clay particle and plasticity index. It is confirmed with the results of activity number analyses based on Skempton [18] that shown in Tab. 3 and 4. Its results show that soil samples in research area has range of activity number (A) from $0.705-1.4931$ (medium to very high).

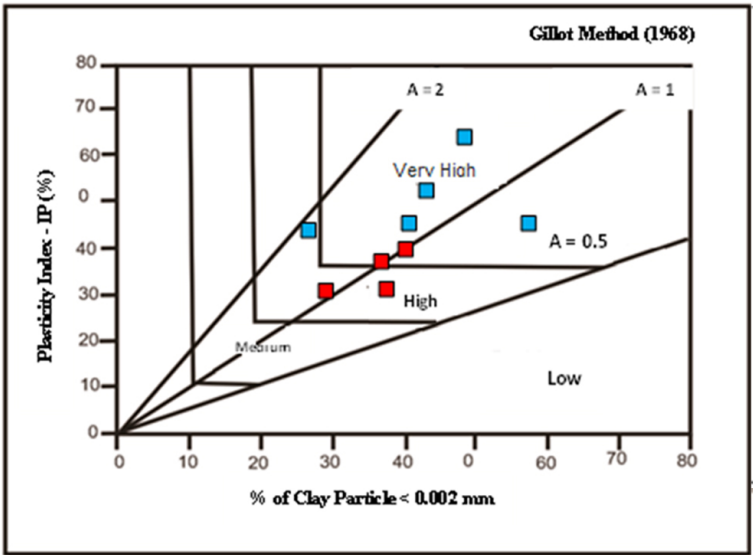

Fig. 3. Diagram of Gillot Method [15]. 
Table 3. Activity number noil at toe of the slope

\begin{tabular}{|c|c|c|c|}
\hline Sample & Depth (m) & $\begin{array}{c}\text { Activity } \\
\text { Number (A) }\end{array}$ & Activity \\
\hline UDS 1 & $0.00-0.50$ & 1.099 & High \\
\hline N/A & N/A & N/A & N/A \\
\hline UDS 2 & $1.00-1.50$ & 1.268 & Very High \\
\hline UDS 3 & $1.50-2.00$ & 1.004 & High \\
\hline UDS 4 & $2.00-2.50$ & 1.2566 & Very High \\
\hline
\end{tabular}

Table 4. Activity number soil at top of the slope

\begin{tabular}{|c|c|c|c|}
\hline Sample & Depth (m) & $\begin{array}{c}\text { Activity } \\
\text { Number (A) }\end{array}$ & Activity \\
\hline UDS 1 & $0.00-0.50$ & 1.248 & High \\
\hline N/A & N/A & N/A & N/A \\
\hline UDS 2 & $1.00-1.50$ & 0.705 & Medium \\
\hline UDS 3 & $1.50-2.00$ & 0.9717 & High \\
\hline UDS 4 & $2.00-2.50$ & 0.922 & Very High \\
\hline UDS 5 & $2.50-3.00$ & 1.4931 & Very High \\
\hline
\end{tabular}

Figure 4 shows the relationship between activity number of soil and percentage of clay particles. It shows that soil samples derived from slopes have range of activity from medium to very high. It is in line with previous method, i.e. Gillot Method [1] and Skempton [2].

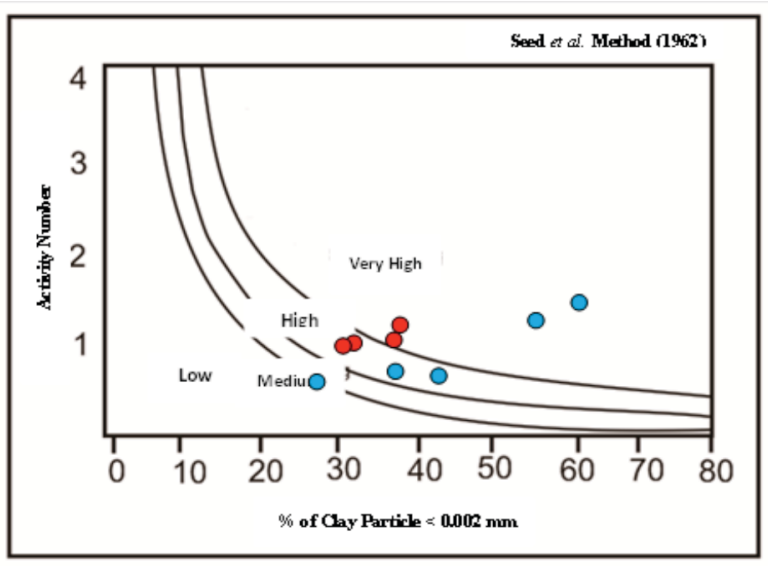

Fig. 4. Diagram of Seed et al. Method [16].

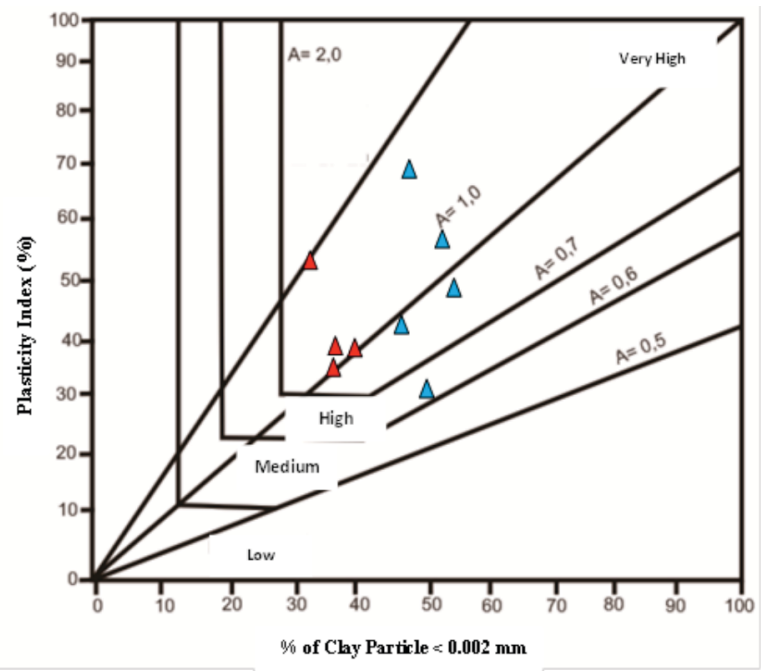

Fig. 5. Diagram of William and Donaldson Method [17].
Activity number (A) analysis using William and Donaldson Method [3] also shows that the activity distribution of soil in research area is ranging from high to very high activity (Fig. 5). It is, once more confirm that soil in research area has high to very high activity.

Based on Casagrande [14], Gillot [15], Seed et al. [16], and William and Donaldson [17] method, it can be linked that creep occurrence in Pagelaran was influenced by the high activity of soil that formed the slope. This high activity can be caused by active clay mineral, e.g. Montmorillonite or Smectite.

\subsection{Geological structures orientation}

Geological structures in research area are the manifestation of forces that worked inside of the Earth. In Creep location there was not found outcrops that indicate the apppearence of faults or folds. Nevertheless, it was found a lot of joints and cracks on the outcrops of rocks and soil. It was measured the orientation of strike and dip of joint plane using Geological Compass. The data resulted from it then analysed using Dipsto become Rosset Diagram to determine the orientation of main force $(\sigma 1)$.

The main force $(\sigma 1)$ that obtained from geological structures analysis of research area is show the orientation of NE-SW as shown in diagram Rosset of Fig. 4a and 4b. This orientation is in line with slope orientation. It can be interpreted that the slope and the landslide occurrence were affected and influenced by geological structure.

It was also found many cracks in the. These results also confirmed with dominant force that worked in Java Island. Based on Martodjojo (1984), there are three dominant structural lineaments in Java Island, and one of them is Meratus Pattern with NE-SW orientation body of slope. Joints or cracks in it can be access for rainwater to flow inside the slope. It then can change the properties of soil by decreasing the shear strength of soil.
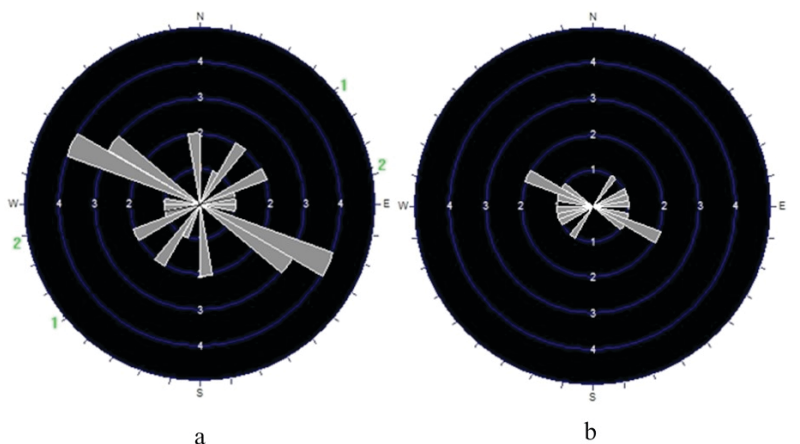

Fig. 6. Joint orientation of rock outcrop (a) and joint orientation measurement of cracks in the body of slope (b)

\section{Conclusion}

Based on Atterberg limits and activity number analyses, it can be concluded that creep occurrence in Pagelaran was influenced by high activity of soil that formed the 
slope. It can be caused by high activity clay mineral. It can be analysed using XRD test for further detail. It is also can be concluded that the creep also influenced by geological structure, especially joints that spread out on and inside the slope. It expressed by same orientation between joints and the slope, i.e. NE-SW. The joints also can be as access for rainfall to flow inside the slope and reduce its stability

Authors want to say thanks Universitas Indonesia for providing funding to conduct this research. A lot of thanks also we give for Nabila Arief who has provided literature for this research. Finally, yet importantly is for Dr. Supriyanto, M.Sc., the Head of Geology Study Program, Universitas Indonesia who always gives valuable support for authors.

\section{References}

1. B. Fatahi, T.M. Le, M.Q. Le, H. Khabbaz. Geomech. Geoeng. (2012) 1-18.

2. D.H. Kang, T.S. Yun, Y.M. Lau, Y.H. Wang. Comput. Geotech. (39) (2012) 98-106.

3. Centre of Volcanology and Geological Hazard Mitigation, Geological Agency (2015).

4. Md. Anisuzzaman, D. Muslim, Arifuzzaman, N. Sadhrina. Proceeding of the 3rd International Conference on Ecological, Environmental, and Biological Sciences, Singapore (2013) 188-191.
5. Ratna Husain, Thesis, Universitas Hasanuddin, Makassar (2015).

6. R.W. Fleming and A.M. Johnson. Eng. Geol., (27) (1989) 39-114.

7. Saro Lee, Ueechan Chwae, Kyungduck Min. Geomorphology, (46) (2002) 149-162.

8. S.A. Dunning, C.I. Massey, N.J. Rosser. Geomorphology, 103 (2009) 17-29.

9. Deying Li, Kunlong Yin, Chin Leo. Environ. Earth. Sci., (60) (2010) 677-687.

10. R.W. van Bemmelen. The Hague. (1949) 442.

11. S. Martodjojo. $\mathrm{PhD}$ Thesis, Institut Teknologi Bandung, Bandug (2003).

12. M. Koesmono, Kusnama, N. Suwarna. Geological Agency, (1996).

13. Braja M. Das, Book. Jakarta: Erlangga (1993).

14. Casagrande. The U.S. Army Corps of Engineer and the U.S. Bureau of Reclamation. (1948).

15. Gillot. Clay in engineering geology. Elsevier Publishing Company (1968) 234.

16. H.B. Seed, R.J.W. Ward, R. Lundgren. Highway res. Board Bull. (1962) 12-39.

17. A.A.B. William and G. Donaldson. Proceeding of 4th International Conference on Expansive Soil, Denver (1980) 834-840.

18. A.W. Skempton.. Geothecnique (4) (1953). 